\title{
Article
}

\section{Knowledge transfer in sustainable management of heritage buildings. Case of Lithuania and Cyprus}

Seduikyte, Lina, Grazuleviciute-Vileniske, Indre, Kvasova, Olga and Strasinskaite, Erika

Available at http://clok.uclan.ac.uk/22265/

Seduikyte, Lina, Grazuleviciute-Vileniske, Indre, Kvasova, Olga and Strasinskaite, Erika (2018) Knowledge transfer in sustainable management of heritage buildings. Case of Lithuania and Cyprus. Sustainable Cities and Society, 40 . pp. 66-74. ISSN 2210-6707

It is advisable to refer to the publisher's version if you intend to cite from the work. http://dx.doi.org/10.1016/j.scs.2018.03.013

For more information about UCLan's research in this area go to http://www.uclan.ac.uk/researchgroups/ and search for <name of research Group>.

For information about Research generally at UCLan please go to http://www.uclan.ac.uk/research/

All outputs in CLoK are protected by Intellectual Property Rights law, including Copyright law. Copyright, IPR and Moral Rights for the works on this site are retained by the individual authors and/or other copyright owners. Terms and conditions for use of this material are defined in the policies page.

\section{CLoK}

Central Lancashire online Knowledge www.clok.uclan.ac.uk

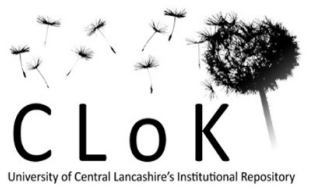




\title{
Knowledge Transfer in Sustainable Management of Heritage Buildings. Case of Lithuania and Cyprus
}

\author{
Lina Seduikyte $^{1 *}$, Indre Grazuleviciute-Vileniske ${ }^{1}$, Olga Kvasova², Erika Strasinskaite ${ }^{1}$ \\ ${ }^{1}$ Kaunas University of Technology, Faculty of Civil Engineering and Architecture, Studentu st. 48, LT- \\ 51367 Kaunas, Lithuania \\ ${ }^{2}$ University of Central Lancashire (UCLan Cyprus), School of Business and Management, 12 -14 \\ University Avenue, Pyla, 7080 Larnaka, Cyprus
}

*Corresponding author: lina.seduikyte@ktu.lt

The article focuses on sociocultural, socioeconomic and environmental sustainability dimensions with respect to heritage buildings and built heritage management knowledge transfer between two European countries - Lithuania and Cyprus. These countries had joined European Union in 2004 and since then had achieved some advancements in implementing the policies of sustainability and sustainable heritage management. The aim of this research was to demonstrate the possible knowledge transfer fields related to heritage and the body of knowledge that can be transferred from Lithuania to Cyprus and vice versa resulting in the positive heritage buildings management innovations. The methods of research included the analysis of literature, the empirical research in heritage objects, and the descriptive analysis of obtained data and selected cases as a form of narrative knowledge transfer. The results of the analysis have demonstrated that balanced country-to-country knowledge transfer can give stimulus to positive heritage buildings management innovations including re-functioning of heritage buildings, the attention to users' comfort in historic structures and low-cost heritage actualisation initiatives.

KEYWORDS: heritage buildings, knowledge transfer, built heritage management, Cyprus, Lithuania

\section{Introduction}

Each country should preserve and investigate the past in order to create the future. With nowadays development paradigms, technologies, knowledge and knowledge exchange possibilities it can be done in a sustainable way. This article is devoted to the sociocultural, socioeconomic, environmental sustainability dimensions and their corresponding aspects - re-functioning, tourism, and energy - with respect to heritage buildings and knowledge transfer in the field of sustainable built heritage management (preservation, renovation, re-use, maintenance, promotion, etc.).

Knowledge transfer. The significance of knowledge in the contemporary life of society cannot be underestimated. Nowadays significant knowledge transfer is going within different types of organizations and between nations, between public and private domains, between businesses, industry and academic institutions. Generally speaking, knowledge transfer can be described as the process through which one entity is affected by the experience of another. This means, that transfer is different from simple information exchange, as it is aimed at capturing, organizing or even creating and distributing knowledge, ensuring its availability, applicability and providing inputs for problem solving in one field or another (Argote and Ingram, 2000; Knowledge... 2017).

The field of heritage management is not an exception from the point of view of knowledge transfer. The review of different sources of literature revealed various types and level knowledge transfer activities in this field including knowledge transfer between professionals and society in the field of preservation of ancient Indonesian manuscripts presented by R. Darmawan (2004), knowledge 
transfer in traditional craftsmanship (Traditional... 2017), knowledge transfer inside country or countryto-country in the field of preservation specific heritage categories, for example, wooden built heritage (Increasing... 2017), and various international or country-to-country experience exchange programs and courses (Exchange... 2015).

Heritage buildings constitute an important asset when striving towards implementing the strategies of sustainability. The existing research and literature demonstrate that the historic built environment can play an important role in all basic dimensions of sustainability: sociocultural (for example, community cohesion, local identity development (Rypkema, 2005)), socioeconomic (creating jobs in heritage preservation sector, development of sustainable cultural tourism, providing other market and non-market economic values (Rypkema, 2005; Ruijgrok, 2006)), environmental (re-use of existing buildings instead of demolition and wasting of embodied energy (Mason, 2005; Philokyprou (2014)). However, the heritage benefits for contemporary and future generations are possible only if the heritage objects themselves are treated sustainably. Literature (Pisello et al. 2016; Sahin et al. 2015; Ascione et al. 2015; Burattini et al. 2015; Harrestrup and Svendsen 2015; Bellia et al. 2015; Todorovic et al., 2015; Philokyprou 2014; Camuffo et al. 2010; Samek et al. 2007) demonstrates that it's possible to integrate smart solutions for renovation and re-use for the changing needs of societies of heritage buildings in order to minimise energy consumption and reduce of $\mathrm{CO}_{2}$ emission without compromising their heritage values. Thus this research applies the concept of knowledge transfer for searching the sustainable heritage management solutions for different contexts.

Hypothesis of the research. Hypothesis of the research is that the fruitful country-to-country knowledge transfer in the field of built heritage management should be based on the optimal balance of congruencies and differences between countries under analysis. Too many similarities might limit the significance and extent of innovations generated through the exchange process; the total lack of social, cultural, economic, geographical etc. congruencies might result in difficulties in finding common ground between countries and successfully adapting knowledge from one context to another (Figure 1).

\section{Country-to-country heritage buildings management knowledge transfer}

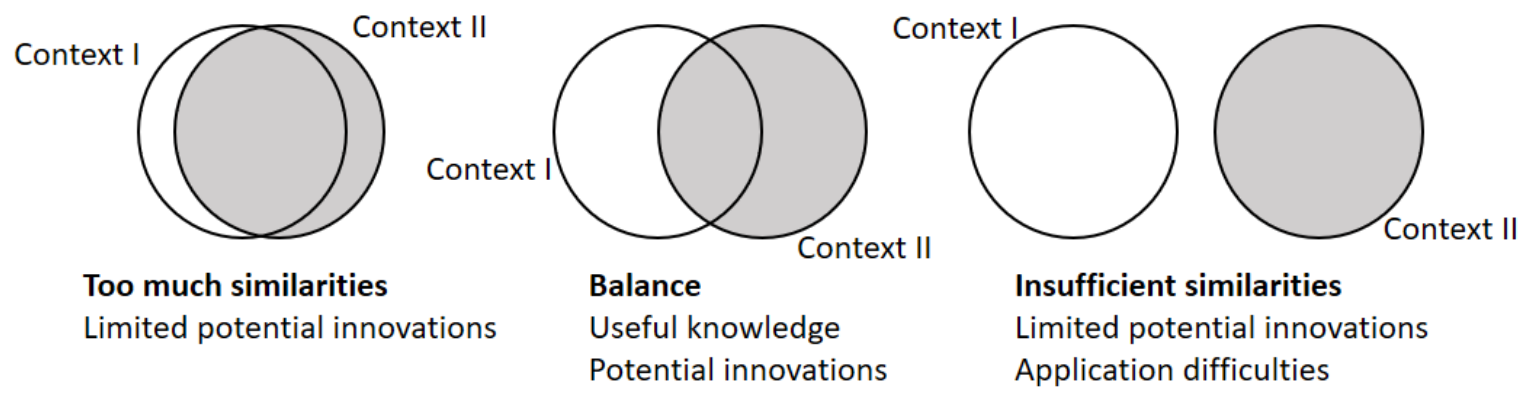

Figure 1. Three generalized situations in country-to-country knowledge transfer in the field of built heritage management. Context I and context II here means two countries with inherent heritage management history, peculiarities and trends potentially participating in the process of knowledge transfer

Object of research. Based on the hypothesis of the research, two European countries - Lithuania and Cyprus - are analysed in this research. These two countries have joined the European Union (EU) in 2004. Both countries have to follow the EU regulations regarding sustainable development and building energy savings and base their built heritage preservation policies on relevant international documents. The following congruencies between two countries beneficial for the knowledge transfer in the field of built heritage management were identified: 
- European cultural tradition and cultural space as a general uniting factor.

- Rich history form prehistory to the $20^{\text {th }}$ century with the corresponding legacy in landscapes and cityscapes and abundance of the built heritage of national and local significance. In this context, it is important that built heritage does not only include cultural monuments of international significance (for example the ones included in the UNESCO World Heritage list). It also includes historical buildings that are important at the national and local level. According to the Venice Charter (1964), these buildings can also be considered historical monuments and therefore, from the point of view of architects and other specialists, they also deserve protection.

- The abundance of diverse heritage determines that both Lithuania and Cyprus have untapped tourism potential related to cultural heritage and especially with built heritage.

- Dynamic and turbulent history of both countries with occupations and government changes influenced both tangible environment and social, cultural, and economic climate as well as the identities of each country. This feature is an important factor influencing the changes of functions and owners of heritage buildings and related contemporary built heritage management challenges.

- Both countries, although very different in size, and overall population, are considered as small countries in the European context. Such countries were inevitably influenced by the more powerful neighbours in the course of their history, and this affected their built heritage development, maintenance and uses and other related spheres.

- $\quad$ - Both countries have relatively similar economic and societal development levels, expressed in such indexes as HDI (Human Development Index) and further demonstrated through similar real GDP growth rates in the past three years (2015-2017), their GDP composition by end use (household consumption, government consumption, investment in fixed capital and inventories, exports and imports of goods and services) and similar distributions of the lowest and the highest $10 \%$ of household income or consumption by GDP percentage share.

The differences that among other should be accounted in the process of knowledge transfer are:

- Climate differences

- The differences of the total area of the country and population density.

- Different historical dynamics and neighbouring influences.

- Geographical and landscape differences.

- Historical building material differences.

- Historical and contemporary urban development differences.

- Institutional differences.

- Different characteristics of the society, cultural differences.

- Economic differences.

- Different legal context.

Aim of research. The peculiarities of Lithuania and Cyprus influence built heritage preservation and management creating both positive and negative unique situations that can be analysed and the experience and knowledge transferred between both countries. This research aims to demonstrate the possible knowledge transfer fields and the body of knowledge that can be transferred from one context to another resulting in positive heritage buildings management innovations.

Methods of research. This article is based on the narrative knowledge transfer. Narratives, socalled storytelling, "have always been communicated as methods of transferring knowledge within society and its subsequent generations. The traditions of oral storytelling that have evolved into our contemporary modes of narrative have been recognized as core to the transfer of knowledge within society" (Tuffield et al., 2005) including inter-country heritage management knowledge transfer. The article presents three descriptions - "short stories" - of heritage buildings preservation and management both from Cyprus and Lithuania. The idea behind the presentation of selected cases from 
the contexts under analysis was "from narrative to understanding and then to action". This narrative knowledge transfer can encourage the broader and more tangible activities, including other categories of knowledge transfer, such as mentorship, simulation, guided experimentation, paired work, community of practice, practices, etc. and other ways to support mutually beneficial collaborations. The material on these cases was obtained from the analysis of literature and empirical research.

The empirical research in two historic church buildings of measurement of internal climate conditions including the measurements of temperature, relative humidity, and carbon dioxide concentrations was carried out for one of the case studies as well. Three cases as the sources of knowledge reflecting three main dimensions of sustainability (sociocultural (sometimes referred as social), socioeconomic (referred as economical as well) and environmental (sometimes referred as ecological)) (Lozano, 2008) were selected:

1. Sociocultural dimension: re-functioning of the historic buildings in the center of Limassol (Cyprus) for the needs of the university as a potential source of knowledge for the management of insufficiently used or abandoned historic buildings in the center of Kaunas (Lithuania), some of which were recently used for the educational purposes as well.

2. Socioeconomic dimension: low-cost heritage presentation and actualisation initiatives in Kaunas (Lithuania) as a potential source of knowledge for the sustainable integration of heritage building in the tourism sector in Cyprus.

3. Environmental dimension: the analysis of internal climate conditions of two heritage buildings - historic churches - in Kaunas and in Rumsiskes town near Kaunas (Lithuania) as a source of knowledge for both contexts that searching for the means of energy saving in heritage buildings the internal conditions, that are of crucial significance both for users and artworks, must be considered.

The description and analysis of selected cases are presented in the chapters below. Each chapter is organized accordingly: the general relevance of the heritage preservation question under analysis is revealed, the context for which the knowledge can be relevant is presented and the selected case as the potential source of knowledge is outlined.

\section{Sociocultural dimension: re-functioning of heritage buildings for educational use}

General relevance. The practice of reusing an existing building is almost as old as building itself (Philokyprou, 2014). For the continuity of traditional built environments, certain rehabilitation and preservation policy should be developed. The success of any policy of integrated heritage preservation depends on taking social factors into consideration. The heritage related actions should involve all the "players": officials from governmental institutions, architects, engineers, scientists, developers and entrepreneurs, communities, commuters, potential visitors etc. The experience of many countries demonstrates that renovation, re-functioning or conversion of historic buildings for contemporary uses is a tool for carrying the traditional environments into future both physically and socially. It is essential for heritage buildings to meet the needs and expectations of contemporary society. The socially responsible re-functioning of heritage buildings should include both saving and presenting history for the present and future generations and sustainably using the buildings for today's needs.

The context for knowledge transfer. University as educational institution is of unquestionable importance and prestige; however, the universities in contemporary changing world under the conditions of global competition think of various ways to enhance their attractiveness and visibility through the built environment. The iconic buildings by star-architects of today is one of the ways to enhance the visibility. However, this requires massive investments into newly built structures that are not always as socially and environmentally friendly as it is declared. Take for example the case of the University of Cincinnati forced to renovate the 1999 building because of the aging roof and other problems, designed by noted American architect Frank Gehry; the intervention into this relatively new iconic structure could cost as much as 17 million US Dollars (Saker, 2017). The adaptation of heritage 
buildings to the needs of university institution in Cyprus could be an experience worth transferring to Lithuanian context, where continuous high education reforms are taking place, and universities compete both in the national and international levels. Moreover, Lithuanian second largest city Kaunas is known and increasingly advertised in the international context for its inter-war era architecture of modernism. Kaunas was awarded the European Heritage Label due to this category of built heritage (Kaunas..., 2017). Inclusion of Kaunas modernist architectural heritage into UNESCO World Heritage List is anticipated as well. However, not so much debated fact is that some outstanding public buildings of inter-war modernism located in the center of Kaunas, including the Central Post Office designed by Feliksas Vizbaras and constructed in 1931, the former office of "Pazanga" company designed by the same architect and constructed in 1931 - 1934, the former headquarter of milk processing company "Pieno centras" designed by another famous Lithuania architect of that era Vytautas LandsbergisZemkalnis, constructed in1931 - 1934, which are awarded the honour to be marked with the table with the European Heritage logo, are just partially used and stand almost abandoned (Figure 2). The unheated buildings start to deteriorate much more rapidly in Lithuanian climate. As the education institutions in Kaunas increasingly shun away from heritage buildings and invest in new structures, the experience of Cyprus city Limassol and Technological University of Cyprus presented by $\mathbf{M}$. Philokyprou (2014) could be useful in reversing this trend and encouraging sociocultural activation and educational use of heritage buildings.

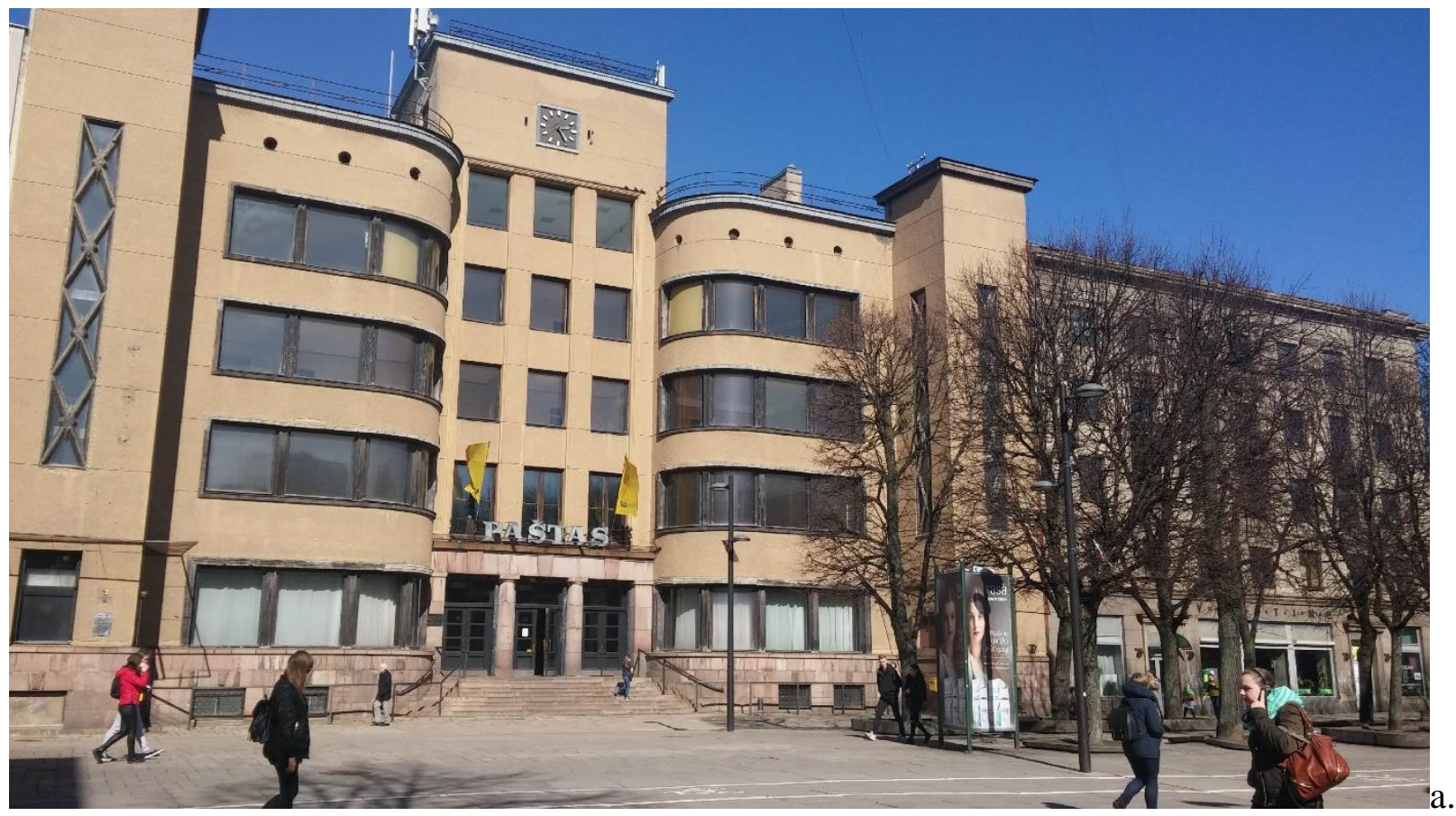



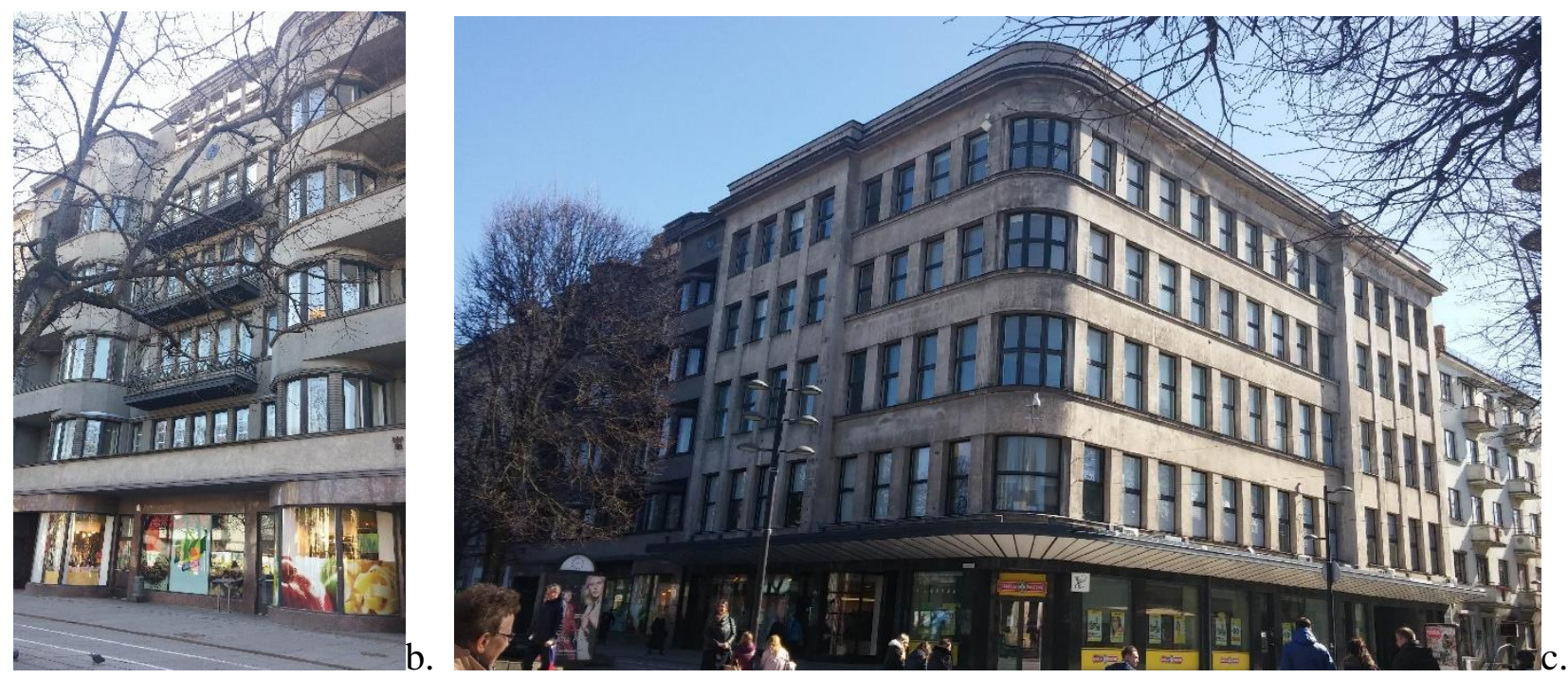

Figure 2. Buildings of Kaunas inter-war modernism

a. The Central Post Office; b. The former office of "Pazanga" company; c. The former headquarter of milk processing company. Photographs by the authors

The potential source of knowledge. The buildings from different historical periods can be found in the historic center of Limassol. Historic churches, mosques, industrial buildings (including wineries), and theatres often cluster in the same area, colonial buildings that were built during the British occupation of the island are present there as well. Until recently the majority of these buildings were in poor condition. All the historic buildings in the center of Limassol have been named as "Ancient Monuments" under the Antiquities Law and since 1982 almost all of the traditional buildings in the historic center have been declared as "Listed" in accordance with the Town and Country Planning Law (Philokyprou, 2014).

Inserting the functions of the University into historical center of Limassol was government's decision with the socially responsible intent to change the social, economic and urban make- up of the area around the city centre. The historic government buildings were given to the University and have been renovated. This sustainable decision has led to the revival of the area which was deteriorating and not properly functioning for the past years and attracting the public with the introduction of educational functions (The development..., 2014; Philokyprou, 2014; Cyprus..., 2017). All the re-functioned buildings analysed in the extensive study by M. Philokyprou (2014) are built from stone, one or two stories high, with timber roofs and ceramic tiles. They have some neoclassical, colonial or even eclectic characteristics. The proposals for the conservation and renovation of these buildings were prepared by the teams of private architects and engineers selected by the University. These proposals were submitted to the municipality of Limassol, and later transmitted to the Conservation Section of the Town Planning and Housing Department for the relevant permissions (Philokyprou, 2014). The following transformations were made (The development..., 2014; Philokyprou, 2014; Cyprus..., 2017):

- The Old Courthouse was transformed into the University Educational Library.

- In the central courtyard of the Old Girls' School building a new elliptical contemporary structure with a slightly vaulted roof was built to function as a large public hall.

- The Old Post Office was selected to host the Rector's and Council Offices. Interior spaces were transformed by removing the partition walls in order to create a larger unified area for conferences. 
- The Limassol Municipal library was further used as an electronic library, thus preserving its previous use. According to M. Philokyprou (2014), its conversion into an electronic library did not demand any additional loads on its already problematic structure.

This experience shows that even moderate buildings can be re-functioned as facilities of contemporary education institution and the range of interventions from new superstructures to slight changes of functions demonstrates again the flexibility and adaptability of heritage buildings.

\section{Socioeconomic dimension: bottom-up low-cost drivers for sustainable cultural tourism}

General relevance. History and culture are important for tourism development, as tourism cannot be restricted to spending leisure time outside and physical activities (relaxing, swimming, sun-bathing, practicing sport); it should include intellectual, cultural and spiritual experiences. Moreover, cultural tourism nowadays is seen as the most sustainable form of heritage-based tourism. Development of tourism, and especially heritage based sustainable cultural tourism, is important both for Lithuania and Cyprus. For example, the tourism sector is one of the major pillars of the economy of Cyprus, and heritage tourism is its essential part (Aristotelous-Cleridou, 2009). The tourism market in Cyprus has experienced substantial growth over the last five years, with tourists averaging around 2.315 million per year (Statistical..., 2017).

The context for knowledge transfer. The promotion of tourism in Cyprus has focused primarily on the concept of "sun and sea", and this creates a seasonality to tourism which means there is an uneven spread of tourism inflow over the year. The government of Cyprus, in an attempt to reduce the tourism seasonality effect, has increasingly been trying to introduce alternatives to complement "sun and sea" by offering holidays focusing on cultural heritage. As a result, cultural tourism has emerged as an important component of tourist activity, based on the rich cultural resource base of the island (Cyprus Tourism..., 2017). Heritage is a challenging touristic "product". The tourism activities should support the continuity of these cultural and historical assets. The essence of cultural tourism lies in recognizing the unique qualities of the area and making the best cultural and economic use of them (Dincyurek and Turker, 2007). The economic returns from cultural tourism can be significant (Dadswell and Beyers, 2006, 2007; Nypan, 2007); and sometimes just low-cost kick-start activities are needed to attract the attention of potential visitors.

The potential source of knowledge. The recent rise in social initiatives linked with heritage buildings in Lithuania and especially in the second largest city Kaunas is worth noting as a set of bottom-up low-cost drivers promoting sustainable cultural tourism related with heritage buildings and could become an easy transferable experience for heritage promotion in Cyprus.

The "Ekskursas" is Kaunas based voluntary gathering, a temporary initiative of architects, historians, art critics, heritage preservationists and other interested people supported by the Architecture and Urbanism Research Centre in the Institute of Architecture and Construction of Kaunas University of Technology. Lithuanian word "Ekskursas" derives from Latin "excursus" meaning digression or incidental excursion from the main topic, as in a narrative. The initiative was encouraged by the above-mentioned granting the European Heritage Label to Kaunas modernist architecture and its main activities took place in 2015 - 2016. The aim of the gathering "Ekskursas" was to direct the attention of society both at local and international levels to this unique layer of history, that due to the efforts of professionals and enthusiasts is already gaining the international recognition. According to the founders of the initiative, three words "discovery", "learning", "surprise" would fit best to describe the goals and character of "Ekskursas" activities. The activities involve both opening to the society for free visits the architectural landmarks of the inter-war modernism and organizing short 30-40 minutes unconventional guided tours at first in the well-known inter-war modernist buildings and further the initiatives of "Ekskursas" expanded to encompass architecture of the Tsarist era and the Soviet period. The guided tours included the visits into spaces and parts of the buildings that are not every day open to 
the public accompanied by the inventive narratives on the significance of these buildings in history, culture, and identity, the changes of functions, etc. The organizers underline, that the widely advertised in social media events first of all should be seen as "the kick" to the inhabitants of Kaunas making them to face the surrounding heritage, that although gaining the increasing international recognition, still is often unnoticed and even undervalued by its everyday users (Kaunas..., 2016; Ekskursas..., 2015; Eksursas, 2016).

Another worth noting activity, generated by the bottom-up initiatives of the architectural, heritage, and research community that helped to promote the city of Kaunas and its heritage both as a cultural tourism "product" and the object of professional and scientific interest at national and international levels and demonstrated various efficient low-cost urban activation initiatives, including the temporary use of buildings for unconventional purposes, was Kaunas Architectural Festival (KAFE). The first festival was organized in 2013, and its success encouraged organizing KAFE 2016 under the slogan "Restart your city center" aimed at "reloading" the attitudes towards the city and its unique heritage layers. The urban and architectural spaces activation events in 2016 included lectures, workshops and exhibitions organized at different and sometimes unusual locations, including abandoned building, lobby of the university building; even the pedestrian spaces in the city center were used as exhibition areas for projects, photographs, and objects. The space of the abandoned and architecturally and economically unsuccessful shop building in the city's central pedestrian avenue was temporarily re-functioned as meeting, discussion, and exhibitions space. Various events were aimed both at professional architects, researchers, and society promoting communication and exchange of ideas and attitudes. The organizers of the festival declare that "the more inhabitants of the city and Lithuania will learn about architecture and its invisible aspects, the more effective will be the debates concerning architecture and urban development between different social groups" (Kaunas..., 2016; Kauno..., 2016).

\section{Environmental dimension: monitoring for energy and users comfort in heritage buildings}

General relevance. Historic buildings constitute 25 percent of the European built environment and have an important role to play in delivering $\mathrm{CO}_{2}$ emissions reduction targets along with the rest of the domestic stock. Buildings of European countries use almost 40 percent of the global energy. This generates 40-50 percent of the total output of greenhouse gases (Moran et al., 2014). Heritage buildings generally use more energy compared to the buildings which were built recently. The implementation of the sustainable renovation of heritage buildings represents a huge challenge, which gives a significant impact on the global energy consumption.

The context for knowledge transfer. It is acknowledged that renovation in order to increase energy efficiency of heritage buildings should be done with respect to their historical, architectural, and sociocultural values. For example, Pisello et al. (2016) presented study of Palazzo Gallenga Stuart, a four story university building in central Italy, where combination of the two effects leads to an average energy saving of 64 percent for heating and 69.2 percent for cooling. The results of Sahin et al. (2015) research showed that energy savings of more than 34 percent could be obtained without damaging the heritage values. Moreover, it is important to note, that heritage buildings, should also meet required indoor microclimate conditions for comfort of contemporary users and preserving artworks and other valuable interior features. The thermal comfort and the preservation of artworks are often in conflict with each other, so a balance between these two is needed as well. The balanced attitude towards energy savings in heritage buildings, creating favourable conditions for the preservation of interior artworks and indoor comfort for the building's users is relevant both to Lithuanian and Cyprus contexts.

The potential source of knowledge. The case of experimental monitoring of two heritage buildings - historic churches - was selected to represent the environmental and users' comfort aspects 
in this heritage management knowledge transfer study. The cultural heritage values representing Lithuanian history of the $15^{\text {th }}$ - the $20^{\text {th }}$ centuries are very well reflected, preserved and represented in Lithuanian churches and monasteries. These buildings are valuable historical structures containing significant artworks and for centuries used by the changing society and thus must ensure an appropriate indoor environment for the contemporary users as well. The aim of the field study - monitoring carried out in Lithuania (in the cold season of 2015) was to evaluate thermal conditions in two heritage buildings - churches - with different wall construction (wooden and masonry) and heating methods (central and local heating). Both churches are included in Register of the cultural heritage of Lithuania.

Masonry church (Figure 3) of Blessed Virgin Mary's Assumption into heaven popularly known as Vytautas Magnus church selected for this research was built in the $15^{\text {th }}$ century, on the north bank of Nemunas river. It was built for Franciscan monks and foreign merchants. Being close to the river it has suffered from spring foods. The church was constructed in Gothic style, has the layout of Latin cross and is a unique example of Lithuanian Gothics. The church has natural ventilation with central heating system.

Wooden church (Figure 4) of St. Michael Archangel in located in Rumsiskes town, which was built in the $18^{\text {th }}$ century. Church has characteristic ethnic architectural elements. Church has natural ventilation and local heating. Six electrical radiant heaters are used for the heating; they are switched on $5-10 \mathrm{~min}$. before the mass.

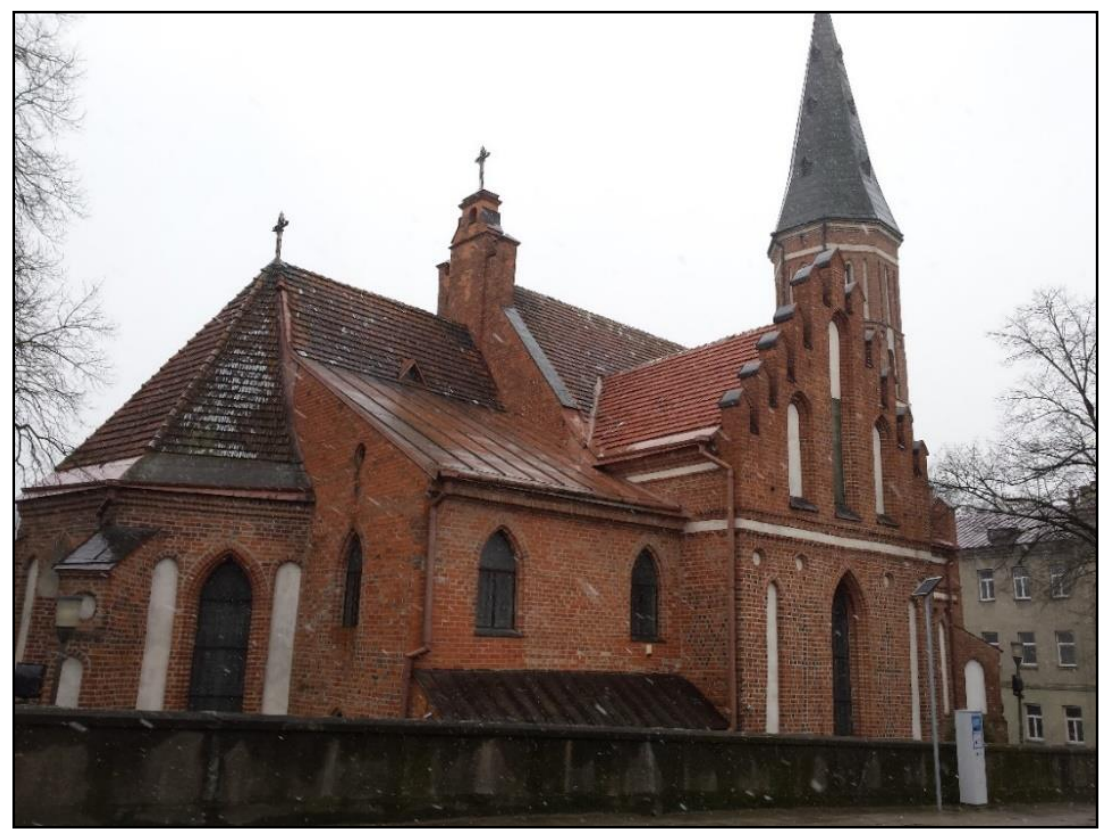

Figure. 3. Church of Blessed Virgin Mary's Assumption into heaven (Vytautas Magnus church). Photograph by the authors 


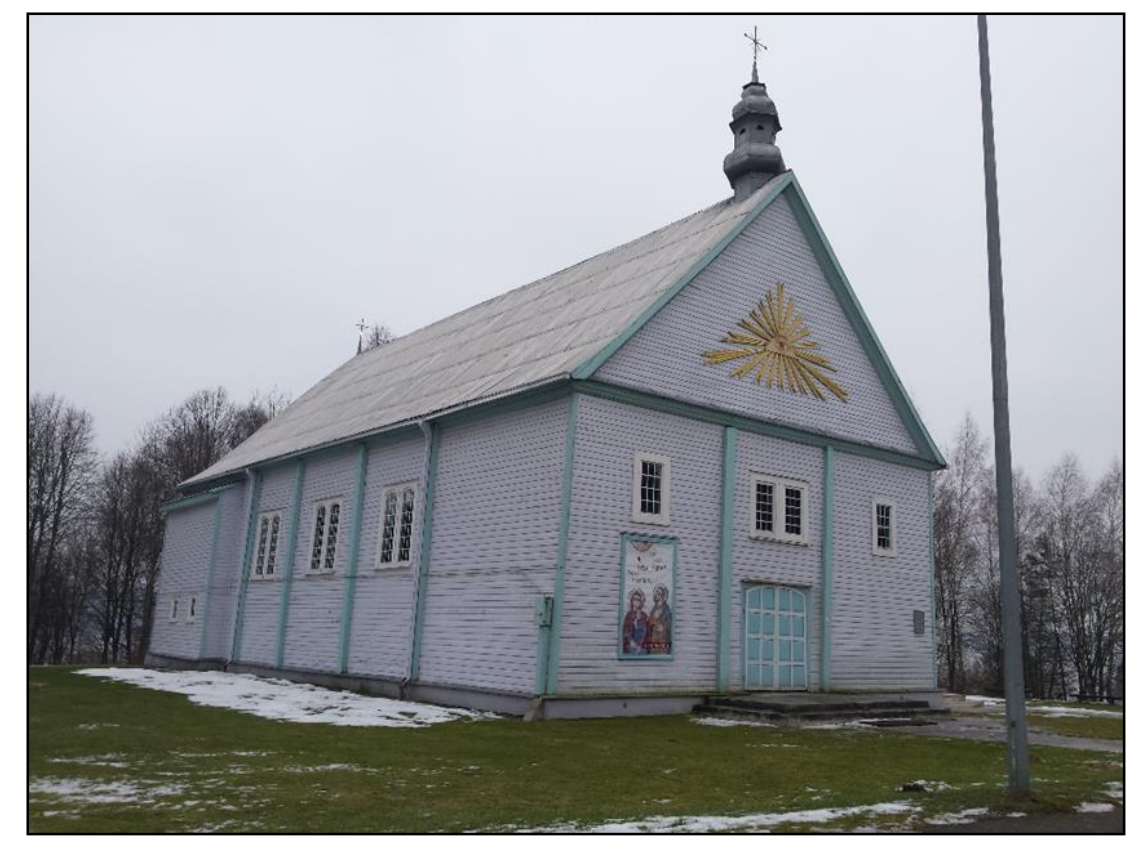

Figure. 4. St. Michael Archangel church of Rumsiskes. Photograph by the authors

For the measurements of temperature and relative humidity, HOBO sensors were used. Sensors were attached to the stand at $0.1 \mathrm{~m}, 0.6 \mathrm{~m}, 1.1 \mathrm{~m}$, and $1.7 \mathrm{~m}$ height, to check temperature differences above the floor for standing person, for seated person and for the ankle level. One stand with HOBO sensors was placed in the middle of Rumsiskes church. Two stands (near altar stand Nr. 1 and in the middle of the church stand Nr. 2) were placed in Vytautas Magnus church. The additional 5 sensors were placed in critical places - in the balcony, near the organ instrument.

Measurements of carbon dioxide $\left(\mathrm{CO}_{2}\right)$ concentration was used as an indicator of indoor air quality and ventilation effectiveness. In both churches, measurements of $\mathrm{CO}_{2}$ concentration started one hour before mass and continued during two masses, which were held one after another. Fluke 975 was used for $\mathrm{CO}_{2}$ measurements.

The Predicted Mean Vote (PMV) refers to a thermal scale that runs from cold ( -3$)$, cool $(-2)$, slightly cool (-1), neutral (0) to slightly warm $(+1)$, warm $(+2)$ hot $(+3)$. PMV was originally developed by Fanger and later adopted as an ISO standard. As presented in ISO 7730, it is probably the index of thermal comfort most widely used for assessing moderate indoor thermal environments. The required input variables are air temperature, mean radiant temperature, air speed, humidity, metabolic rate, and the insulation of the clothing. The insulation for clothing for winter season was calculated as 1.2 clo. Metabolic rate was taken as 1.2 met (for relaxed siting is 1 met, for standing $-1.2 \mathrm{met}$ ).

Predicted Percentage of Dissatisfied (PPD) predicts the percentage of occupants that will be dissatisfied with the thermal conditions. It is a function of PMV, given that as PMV moves further from 0 , or neutral, PPD increases. The maximum number of people dissatisfied with their comfort conditions is 100 percent. Recommended acceptable PPD is less than $10 \%$ persons dissatisfied for an interior space.

For the evaluation of PMV and PPD values INNOVA system was used.

According to Lithuanian hygiene norm $\mathrm{HN}$ 42:2009 "Microclimate in dwellings and public buildings", indoor temperature for heating season should be in the range of $18-22{ }^{\circ} \mathrm{C}$, relative humidity in the range of $35-60$ percent. However, according to $\mathrm{HN} 42: 2009$, if the coats and other worm clothes are kept indoors, temperature in such dwellings should be in the range of $14-16{ }^{\circ} \mathrm{C}$. 
Results of measured temperature and relative humidity are presented in table 1. Temperature differences at different heights were not significant, however, measured temperature during winter season was not meeting HN 42:2009 requirements in both churches.

Table 1. Temperature $(\mathrm{T})$ and relative humidity $(\mathrm{RH})$ values measured in tested churches

\begin{tabular}{|c|c|c|c|c|c|c|c|c|c|c|c|c|c|}
\hline \multirow{2}{*}{$\begin{array}{l}\text { Parameter/ } \\
\text { height of } \\
\text { the } \\
\text { instrument }\end{array}$} & \multicolumn{3}{|c|}{$0.1 \mathrm{~m}$} & \multicolumn{3}{|c|}{$0.6 \mathrm{~m}$} & \multicolumn{3}{|c|}{$1.1 \mathrm{~m}$} & \multicolumn{3}{|c|}{$1.7 \mathrm{~m}$} & \multirow[t]{2}{*}{ Church } \\
\hline & Aver & Min & Max & Aver & Min & Max & Aver & Min & $\operatorname{Max}$ & Aver & Min & Max & \\
\hline $\mathrm{T},{ }^{\circ} \mathrm{C}$ & 2.12 & -2.9 & 7.03 & 2.15 & -2.90 & 8.23 & 2.27 & -2.44 & 8.63 & 2.10 & -2.44 & 8.23 & Church of \\
\hline $\mathrm{RH}, \%$ & 76.96 & 47.40 & 88.1 & 80.28 & 50.30 & 92.00 & 77.51 & 43.00 & 88.10 & 77.87 & 43.00 & 89.90 & Rumsiskes \\
\hline $\mathrm{T},{ }^{\circ} \mathrm{C}$ & 10.19 & 9.42 & 14.85 & 10.36 & 9.42 & 15.62 & 10.48 & 9.42 & 15.62 & 10.56 & 9.42 & 15.62 & Vytautas \\
\hline $\mathrm{RH}, \%$ & 65.10 & 46.30 & 85.5 & 71.42 & 54.80 & 89.20 & 24.15 & 23.50 & 24.30 & 64.68 & 46.50 & 85.40 & $\begin{array}{l}\text { Magnus } \\
\text { church, } \\
\text { stand Nr. } 1\end{array}$ \\
\hline $\mathrm{T},{ }^{\circ} \mathrm{C}$ & 10.20 & 9.03 & 16 & 10.09 & 9.03 & 17.14 & 10.42 & 9.42 & 18.28 & 10.56 & 9.42 & 18.28 & Vytautas \\
\hline $\mathrm{RH}, \%$ & 68.41 & 50.80 & 85.5 & 66.45 & 49.60 & 82.50 & 69.41 & 51.00 & 85.52 & 24.14 & 23.40 & 24.30 & $\begin{array}{l}\text { Magnus } \\
\text { church, } \\
\text { stand Nr. } 2\end{array}$ \\
\hline
\end{tabular}

The most critical situation was in wooden church because of insufficient heating. The average temperature at $1.1 \mathrm{~m}$ (for seated person) was $2.27{ }^{\circ} \mathrm{C}$ and at $1.7 \mathrm{~m}$ (for standing person) was $2.10^{\circ} \mathrm{C}$. Relative humidity was also exceeding the limits - in all cases it was higher than 60 percent. In some cases, reaching 90 percent. This is influencing sensation of thermal comfort and is not appropriate for paintings, organ instruments and other heritage features as well. Measurements of PMV and PPD identified that the environment in the wooden church could be described as cold (PMV value was -2), PPD was 76 percent. In the masonry church, PMV value was -0.85 and PPD 20 percent. PMV and PPD values are an additional confirmation of poor thermal conditions in the tested churches.

$\mathrm{CO}_{2}$ measurements showed, that in wooden church $\mathrm{CO}_{2}$ concentration reached $1400 \mathrm{ppm}$, in masonry church $-1811 \mathrm{ppm}$. $\mathrm{CO}_{2}$ results show poor indoor air quality and insufficient ventilation.

The monitoring results had demonstrated unfavourable situation regarding both users' health and comfort and preservation of artworks in the analysed buildings and call for coordinated interventions in order to secure energy efficiency, thermal comfort, and preservation of heritage features. It is no doubt that different climates in Lithuania and Cyprus will require different solutions. Nevertheless, the knowledge, that not only energy but also people are important should be taken into account.

\section{Discussion}

The congruencies and differences between Lithuania and Cyprus identified in the research including the influence of the specific sociocultural and socioeconomic context on the attitudes and actions directed towards cultural heritage in each country allow the fruitful analysis of heritage buildings treatment cases and knowledge transfer and adaptation. The selected cases - re-functioning of the historic buildings in the center of Limassol, low-cost heritage presentation and actualisation initiatives in Kaunas, and the analysis of internal climate conditions of two heritage church buildings in Kaunas and in Rumsiskes town - demonstrated that the balanced inter-country knowledge transfer can give the stimulus for generating the ideas for sustainable heritage buildings management innovations (Figure 5).

Re-functioning of heritage buildings. Some buildings through centuries have kept they primary purpose (for example, castles, churches, private houses), however many of them have changed their primary functions and were continuously reconstructed and adapted to new uses. The turbulent history of both Lithuania and Cyprus resulted in frequent changes of heritage buildings users and functions, the vast differences between the needs of historical and contemporary societies raise the challenges of 
sustainable heritage buildings rehabilitation and re-use as well. The socially responsible re-functioning of heritage buildings for the needs of the university in Limassol illustrates the sociocultural dimension of management of heritage buildings that can be adapted to the case of Kaunas Inter-war modernist architecture. The resilience of historic built environment embodies one of the highest forms of sustainability.

Low-cost, bottom-up community initiatives in the tourism sector. Each country has its own social context peculiarities affecting heritage preservation, interpretation, and promotion. For example, in Cyprus, various successive rulers led to the creation of its multicultural architectural diversity and simultaneously affected the philosophy followed in maintaining monuments. A big influence was done by the industrial revolution and urbanization, which has changed the attitude towards cultural heritage when the relationship between people and the traditional environment was disturbed (Philokyprou and Limbouri-Kozakou, 2015). Meanwhile, the findings of the earlier studies suggest that societies in the post-communist or so-called post-socialist transition countries may lack social initiatives (Grazuleviciute-Vileniske et al. 2014; Grazuleviciute-Vileniske and Urbonas, 2011). However, the emerging bottom-up heritage and urban spaces actualization initiatives form heritage and architecture professionals and enthusiast's community in Kaunas can serve as a viable model in Lithuania, Cyprus and elsewhere both for cultural tourism and society involvement into heritage cognition and preservation purposes.

Energy savings and internal climate in heritage buildings. Lithuanian climate conditions with significant temperature differences in warm and cold seasons and the active use of some heritage buildings, such as churches only in specific hours create the particular challenges in balancing comfortable conditions, energy saving, and preservation of artworks. Thus the research in this field is relevant and should be transferred to different contexts. It is usually considered a prestige to have working or living place in heritage buildings. Sometimes flexible renovation should be accepted, for example, installing sustainable and energy saving heating, ventilation systems or redesigning spaces, in order to keep heritage building "alive" and "find" new owners.

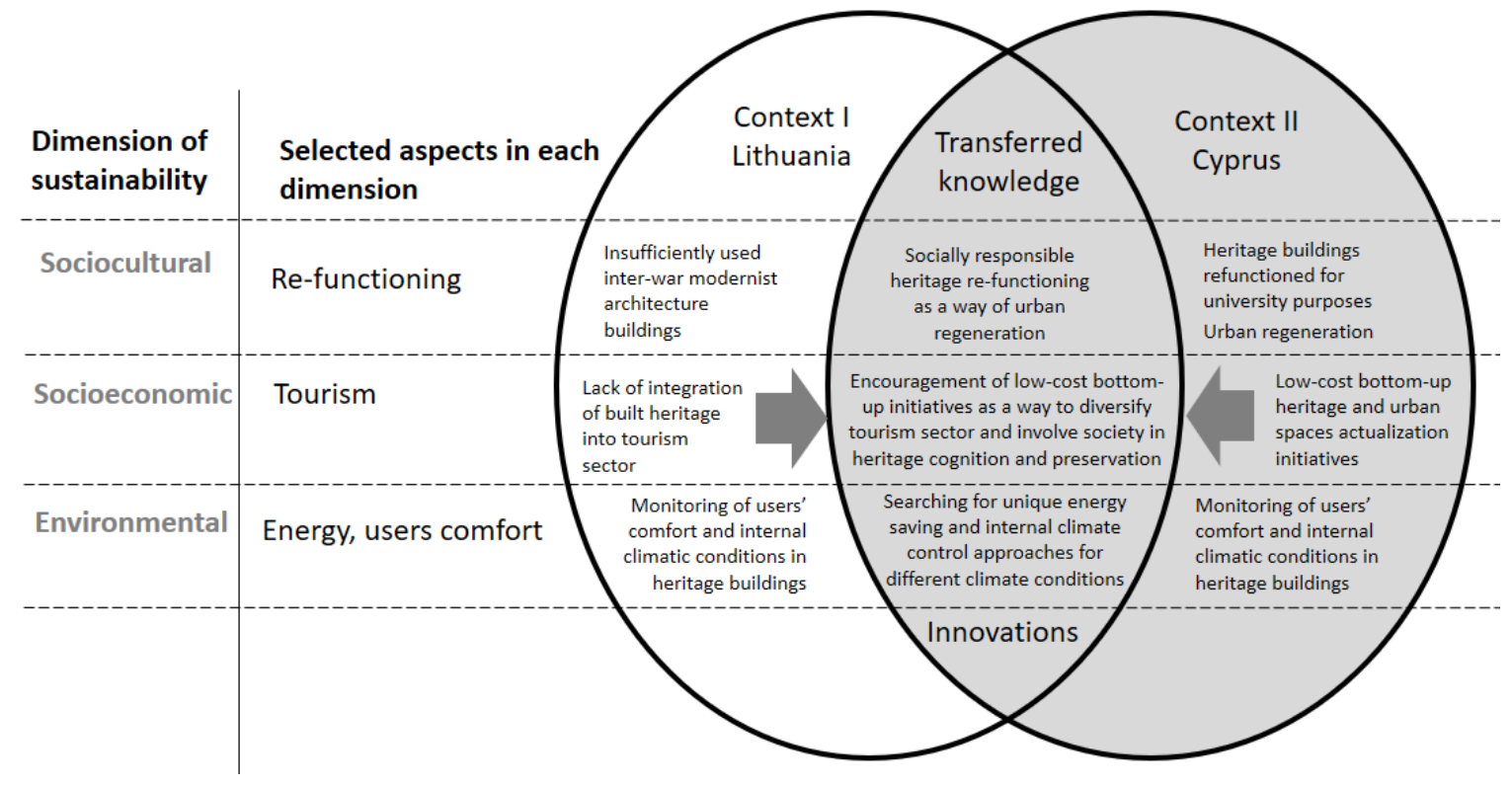

Figure 5. The structure and generalized findings of the study

\section{Conclusions}


1. Inter-country narrative knowledge transfer in heritage preservation sector can become a significant stimulus for further initiatives and other more tangible modes of knowledge exchange and transfer including mentorship, simulation, guided experimentation, paired work, a community of practice, practices etc. based on the idea "from narrative to understanding and then to action".

2. Case studies for knowledge transfer were selected based on the challenges each country is facing and potential sources of knowledge that can be found to match these challenges in heritage preservation sector, including re-functioning of buildings, low-cost bottom-up heritage actualisation initiatives in the tourism sector, the issue of balancing the energy savings in heritage buildings with users' comfort and preservation of the interior artworks. The basic dimensions of sustainability - sociocultural, socioeconomic, and environmental served as a guideline for selecting the case studies in order to illustrate better the spectrum of sustainable heritage management challenges.

3. Cyprus experience of re-functioning heritage buildings for university's needs gives a sustainable example of heritage management that can be adapted in Lithuania bearing in mind the presence of insufficiently used valuable buildings in the historic centers of large cities of the country including the second largest city Kaunas with insufficiently used inter-war era modernist architectural heritage. Instead of constructing new buildings changes in heritage ones are made in order to fulfil nowadays requirements. This shows the efforts to revitalize inner urban areas, to maintain heritage buildings, to build sustainable communities and the responsible attitude towards consumption and production in the building sector.

4. Examples of Lithuanian sustainable community heritage actualisation initiatives in Kaunas showed, that sometimes substantial funding is not needed in order to educate society (both local and international) on unique parts of history of the city or country. These low-cost bottom-up activities, like guided tours and urban and architectural spaces activation events, increase the perception and appreciation of history and heritage and can be applied in different contexts.

5. The monitoring approach to heritage buildings exemplified by the case of Lithuanian churches, when comfort of users is taken into account and the society and the interior artworks should be as much important as energy savings, could be transferred to different contexts including Cyprus.

\section{Acknowledgment}

This work was supported by COST Action TD1406 "Innovation in Intelligent Management of Heritage Buildings (i2MHB)".

\section{References}

Aristotelous-Cleridou A. Cyprus State of Art Report. Cultural Heritage Issues in Relation to Urban Planning Workshop. 2009. http://www.arcchip.cz/w03/w03_cleridou.pdf

Ascione, F., Bianco, N., De Masi R.F., De'Rossi F., Vanoli G.P., 2015. Energy retrofit of an educational building in the ancient center of Benevento. Feasibility study of energy savings and respect of the historical value. Energy and Buildings 95: 172-183.

Bellia L., Alfano F.R.D., Giordano J., Ianniello E., Riccio G., 2015. Energy requalification of a historical building: A case study. Energy and Buildings 95: 184-189.

Burattini C., Nardecchia F., Bisegna F., Cellucci L., Gugliermetti F., Vollaro A., Salata F., Golasi I., 2015. Methodological approach to the energy analysis of unconstrained historical buildings. Sustainability 7(8): 10428-10444. 
Camuffo D., Pagan E., Rissanen S., Bratasz L., Kozłowski R., Camuffo M., Valle A., 2010. An advanced church heating system favourable to artworks: A contribution to European standardisation. Journal of Cultural Heritage 11(2): 205-219.

Cyprus Tourism market report. 2017. https:/home.kpmg.com/cy/en/home.html

Cyprus University of Technology. 2017 http://web.cut.ac.cy/postharvest/cyprus-university-oftechnology/

Dadswell M., Beyers W. B. The economic benefits of historic preservation. Summary report. Washington Department of archeology and historic preservation, Washington 2006.

Dadswell M., Beyers W. B. The economic benefits of historic preservation. Technical report. Washington Department of archeology and historic preservation, Washington 2007.

Darmawan R. 2004. Publishing a community-based knowledge-transfer device within the framework of cultural heritage preservation, management, promotion and education. International Information \& Library Review Volume 36, 2004 - Issue 3 209-217

Ekskursas - niuksas tingiems rudens savaitgaliams. 2015.

http://www.kamane.lt/Naujienos/Architektura/Ekskursas-niuksas-tingiems-rudens-savaitgaliams Ekskursas. 2016. http://kafe2016.lt/en/\#home

Exchange Generates Ideas for Preserving Mali's Rich Cultural Heritage. 2015. https://exchanges.state.gov/us/story/exchange-generates-ideas-preserving-malis-rich-culturalheritage

Gražulevičiūtè-Vileniškè, Indrè; Janilionis, Vytautas; Guščinskienè, Jūratė; Ažukaitè, Ligita. Contingent valuation of built heritage properties in a transition country : a case of Lithuania // International journal of strategic property management. Vilnius: Technika ; London: Taylor \& Francis. ISSN 1648-715X. 2011, vol. 15, no. 4, p. 393-415.

Gražulevičiūtè-Vileniškè, Indré; Urbonas, Vilius. Urban regeneration in the context of post-Soviet transformation: Lithuanian experience. Journal of cultural heritage. Paris: Elsevier. ISSN 12962074. 2014, vol 15, iss. 6, p. 637-643.

Harrestrup M., Svendsen S., 2015. Full-scale test of an old heritage multi-storey building undergoing energy retrofitting with focus on internal insulation and moisture. Building and Environment 85: 123-133.

Increasing Knowledge about preservation of wooden heritage http://eeagrants.org/News/2016/Increasing-knowledge-about-preservation-of-wooden-heritage

Argote, L.; Ingram, P. (2000). "Knowledge transfer: A Basis for Competitive Advantage in Firms". Organizational Behavior and Human Decision Processes. 82 (1): 150169. doi:10.1006/obhd.2000.2893

Kaunas Architectural Festival 2016 http://kafe2016.lt/kafe-2016-ekskursas-iii-ciklas/

Kauno architektūros festivalis: dirbtuvès, paskaitos, diskusijos, parodos 2016. http://www.kamane.1t/Naujienos/Architektura/Kauno-architekturos-festivalis-dirbtuves-paskaitosdiskusijos-parodos

Kaunas was awarded a European Heritage Label http://visit.kaunas.lt/en/to-see/interwararchitecture/kaunas-was-awarded-a-european-heritage-label/

Knowledge Transfer 2017 http://www.cam.ac.uk/research/news/what-is-knowledge-transfer

Lozano R., 2008. Envisioning sustainability three-dimensionally. Journal of Cleaner Production 17 (16): $1838-1846$.

Mason R. Economics and historic preservation: a guide and review of the literature. Discussion paper prepared for the Brookings Institution Metropolitan Policy Program, Washington 2005.

Moran F., Blight T., Natarajan S., Shea A., 2014. The use of Passive House Planning Package to reduce energy use and CO2 emissions in historic dwellings. Energy and Buildings 75: 216-227.

Nypan T. Cultural heritage monuments and historic buildings as value generators in a post-industrial economy. With emphasis on exploring the role of the sector as economic driver. Paper presented in 
the Nordic Networking Event Economics and Built Heritage, Hameenlinna 2007. Prieiga per internetą: http://www.ebheritage.fi/research/articles+papers/index.php?action=show_results

Philokyprou M. Adaptation of new university uses in old buildings: the case of rehabilitation of listed buildings in Limassol Cyprus for university purposes. 2014/ International Journal of Architecture Heritage, 8: 758-782.

Philokyprou, M. and Limbouri-Kozakou, E. 2015. An overview of the restoration of monuments and listed buildings in Cyprus from antiquity until the twenty-first century. Studies in Conservation 60 (4). $267-277$.

Pisello A.L., Petrozzi A., Castaldo V.L., Cortana F., 2016. On an innovative integrated technique for energy refurbishment of historical buildings: Thermal-energy, economic and environmental analysis of a case study. Applied Energy 162: 1313-1322.

Ruijgrok E. C. M. The three economic values of cultural heritage: a case study in the Netherlands. Journal of Cultural Heritage 7, 2006: 206 - 213.

Rypkema D. Cultural heritage and sustainable economic and social development. Paper presented at European Cultural Heritage Forum, Cultural Heritage Counts for Europe, Europa Nostra, Brussels 2005. rypkema_keynote_address_07dec_05.pdf

http://www.europanostra.org/downloads/speeches/donovan-

Sahin C. D., Arsan Z.P., Tuncoku S.S., Brostrom T., Akkurt G.G., 2015. A transdisciplinary approach on the energy efficient retrofitting of a historic building in the Aegean Region of Turkey. Energy and Buildings 96: 128-139.

Saker A. 2017. Iconic UC building needs repairs after less than 20 years. http://www.cincinnati.com/story/news/2017/01/17/iconic-uc-building-needs-repairs-after-lessthan-20-years/96673280/

Samek L., Maeyer-Worobiec A., Spolnik Z., Bencs L., Kontozova V., Bratasz L., Kozlowski R., Grieken R., 2007. The impact of electric overhead radiant heating on the indoor environment of historic churches. Cultural Heritage 8: 361-369.

$\begin{array}{llll}\text { Statistical Service. } & \text { Republic } & \text { of } & \text { Cyprus. }\end{array}$ http://www.mof.gov.cy/mof/cystat/statistics.nsf/services_71main_en/services_71main_en?OpenFo $\mathrm{rm} \& \mathrm{sub}=1 \& \mathrm{sel}=1$

The development of the city in co-existence with the Cyprus University of Technology. 2014 http://www.limassolmunicipal.com.cy/pdf/change2014_en.pdf

Todorovic M.S., Ecim-Duric O., Nikolic S., Ristic S., Polic-Radovanovic S., 2015. Historic building's holistic and sustainable deep energy refurbishment via BPS, energy efficiency and renewable energy-A case study. Buildings 95: 130-137.

Traditional Craftsmanship. 2017. http://www.unesco.org/culture/ich/en/traditional-craftsmanship00057

Tuffield M. M., Shadbolt N. R., Millard D. E., 2005. Narrative as a form of knowledge transfer: narrative theory and semantics. 1st AKT Doctoral Symposium, United Kingdom https://eprints.soton.ac.uk/id/eprint/261010 